tion methods considered are very similar in efficiency. The first, based on individual boar testing, is recommended because of its low cost in present economic conditions, if pig fattening profit is to be rapidly improved in France. The gain per generation of this selection method is 7 FF per fattened pig, if the higher $20 \mathrm{p}$. Ioo of tested boars are kept for reproduction.

\title{
EFFICACITÉ COMPARÉE DES DIFFÉRENTES MÉTHODES DE SÉLECTION CHEZ LE POHC
}

\author{
A. PEASE \\ Pig Improvement International, 27 - Le Theillement \\ RÉSUMÉ
}

Dans le contexte d'un schéma d'amélioration porcine bien structuré, l'efficacité de quatre formes de test a été comparée par un exemple simplifié et théorique. En supposant que I6 places de testage et 2 ans étaient disponibles pour produire un verrat, la valeur génétique du verrat produit sera la suivante :

Contrôle de la descendance............. o, 40 écart-type

Contrôle fraternel (sib test) $\ldots \ldots \ldots \ldots \ldots \ldots \ldots \ldots, 0,68 \quad-$

Contrôle individuel................... I,30 -

Contrôle combiné.................. I,I $\quad-$ approx.

Il faut utiliser le contrôle fraternel lorsqu'il y a un problème sanitaire et le contrôle individuel ou le contrôle combiné dans les autres cas. C'est souvent le contrôle combiné qui est le meilleur surtout lorsque la sélection intense est pratiquée. La réalisation en est difficile sur le plan pratique avec la coordination des deux moitiés du test et sur le plan génétique avec le calcul de l'indice de sélection. La difficulté d'estimation du grand nombre des corrélations nécessaires à un indice pour un contrôle combiné n'est pas insurmontable. Dans une étude effectuée à la P. I. D. A. 74 erreurs d'une moyenne de o, 13 dans les corrélations ont diminué l'efficacité de l'index par 8,4 $\mathrm{p}$. Ioo. Une perte de cet ordre n'annule pas la valeur de l'indice mais mérite un effort pour le diminuer. 


\title{
SUMMARY
}

COMPARISON OF THE EFFICIENCY OF SELECTION METHODS FOR PIGS

A simplified theoretical example was used to compare four types of test, in the context of a tightly organized improvement scheme. Assuming that 16 test places and 2 years were available to produce one boar the genetic value of the selected animal was as follows :

\begin{tabular}{|c|c|c|c|}
\hline Progeny test . . . . . . . . & $0.4^{\circ}$ & and & riati \\
\hline Sib test. $\ldots \ldots \ldots \ldots \ldots \ldots \ldots \ldots \ldots$ & 0.68 & - & 一 \\
\hline Performance test .............. & I. 30 & -- & $\cdots$ \\
\hline Combined performance and Sib test. & I.I 7 & - & $\longrightarrow$ \\
\hline
\end{tabular}

A combined test is often the best, particularly when selection is intense, but problems of coordinating the two halves of the test and of calculating the selection index make it difficult to put into practice. However, the difficulty of estimating the large number of parameters used in a combined test selection index is not insurmountable. In a preliminary study made for P. I. D. A. 74 errors averaging 0.13 in the correlations reduced the efficiency by $8.4 \mathrm{P}$. Ioo. A loss of this order does not invalidate an index, but it does show that considerable effort should be devoted to improving estimates of parameters.

\section{HLIN ZOOTECHNIQLE JES STATIONS DE CONTHÒLE INDIVIDUEL ET DE CONTRÔLE DE LA DESCENDANCE}

\author{
M. MOLENAT et J. NAVEAU \\ Laboratoive de Génétique quantitative et appliquée, \\ Centre national de Recherches zootechniques, 78 -Jouy-en-Josas \\ Institut national de la Recherche agronomique

\section{RÉSUMÉ}

De très nombreux contrôles sont efiectués sur les Porcs. Il est indispensable d'obtenir une certaine standardisation qui doit porter sur les conditions de contrôle (règlements techniques), sur l'interprétation des résultats, sur leur présentation. Ainsi toutes les comparaisons se font entre contemporains et l'index utilisé en station est toujours de la forme :

$$
\mathrm{I}=\mathrm{A}+a\left(x_{1}-\bar{x}_{1}\right)+b\left(x_{2}-\bar{x}_{2}\right)+c\left(x_{3}-\bar{x}_{3}\right) \ldots
$$

